\begin{tabular}{|l|c|c|c|c|c|}
\hline J. Tek. Ling & Vol.11 & No.1 & Hal. 33 - 38 & Jakarta, Januari 2010 & ISSN 1441-318X \\
\hline
\end{tabular}

\title{
ANALISIS POPULASI NEPENTHES SPP DI HUTAN RAWA GAMBUT, KALAMPANGAN, KALIMANTAN TENGAH
}

\author{
Muhammad Mansur \\ Peneliti di Bidang Botani, Pusat Penelitian Biologi-LIPI \\ Lembaga Ilmu Pengetahuan Indonesia \\ Jl. Raya Bogor Km 46.5 Cibinong, Bogor
}

\begin{abstract}
Population analysis of Nepenthes spp in peat swamp forest was conducted at Kalampangan, Central Kalimantan on November-December 2007. This place include to part of one million hectare area of peat land project in 1996 which are planed to convert agricultural land. Peat swamp forest is one of commonly Nepenthes habitat at Kalampangan. One plot $(50 \times 100 \mathrm{~m})$ was establihed for population analysis study. We found 230 individu from three species, that is; Nepenthes ampullaria, N. rafflesiana and $N$. gracilis. In study site, $N$. ampullaria is dominant species with Important Value (IV) is $120,43 \%$ and then followed by $N$. gracilis (IV=97,30\%) and $N$. rafflesiana (IV= $82,27 \%)$.
\end{abstract}

Key Words : Population analysis, Nepenthes, peat swamp forest, Kalampangan,

\section{PENDAHULUAN}

\subsection{Latar Belakang}

Hutan rawa gambut merupakan bentuk hutan spesial yang unik dan lebih ditekankan pada bentuk habitatnya daripada struktur atau penampakan vegetasinya. Umumnya bentuk hutan seperti ini digenangi air permanen yang bersifat asam $(\mathrm{pH}<4)$ dan lapisan tanahnya terdiri dari tumpukan serasah daun dengan ketebalan antara 1-12 $\mathrm{m}^{11}$. Hanya tumbuhan tertentu saja yang bisa hidup dan beradaptasi di daerah ini. Oleh karena itu tingkat keanekaragaman jenis di tempat ini adalah kecil dibanding dengan hutan dataran rendah.

Hutan gambut di Kalimantan Tengah umumnya berada di antara tiga sungai yaitu sungai Kahayan, Sebangau dan Katingan yang diperkirakan sudah terbentuk selama 10.000 tahun $^{2}$. Sejak tahun 1980, kawasan

hutan rawa gambut mulai terganggu keberadaannya yang diakibatkan oleh perambahan hutan, kebakaran hutan pada tahun 1997 dan 2002 akibat adanya El-nino dan paling besar kerusakannya adalah akibat pembukaan hutan dengan adanya mega proyek penanaman padi sejuta hektar pada tahun 1996.

Hutan rawa gambut di Kalampangan merupakan salah satu hibitat Nepenthes di Kalimantan Tengah. Daerah ini merupakan area mega proyek lahan sejuta hektar yang telah dibuka 12 tahun yang lalu yang direncanakan untuk lahan pertanian khususnya padi, terletak kurang lebih $30 \mathrm{~km}$ dari Palangkaraya. Namun demikian masih tersisa hutan yang tidak dibuka. Sebagian dari areal tersebut kemudian dikelola 
oleh CIMTROP (Center For International Co-operation in Management of Tropical Peatland) Universitas Palangkaraya, untuk kepentingan penelitian.

\subsection{Tujuan Penelitian}

Penelitian bertujuan untuk mengetahui keanekaragaman dan populasi Nepenthes di kawasan Hutan Rawa Gambut, Kalampangan, serta untuk mengetahui karakteristik masing-masing jenis guna kepentingan konservasinya. Diharapkan hasilnya dapat menambah data keragaman tumbuhan yang berpotensi untuk dikembangkan guna mendukung pengembangan tumbuhan di kawasan ini.

\section{METODOLOGI}

\subsection{Waktu dan Tempat Penelitian}

Penelitian dilakukan pada bulan November-Desember 2007 di Desa Kalampangan, Kecamatan Sebangau, Kota madya Palangkaraya, Propinsi Kalimantan Tengah.

\subsection{Pengumpulan Data}

Survei di dilakukan dengan cara penjelajahan untuk inventarisasi jenisjenis Nepenthes yang hidup di daerah penelitian. Setiap jenis yang ditemukan diambil gambarnya, dideskripsi, diidentifikasi dan dibuat herbariumnya sebagai spesimen bukti yang kemudian disimpan di Herbarium Bogoriense-LIPI, Cibinong.

Metoda kuadrat dengan membuat plot seluas 0,5 ha $(50 \times 100 \mathrm{~m})$ diterapkan untuk menaksir populasi Nepenthes dan penyebarannya. Plot kemudian dibagi lagi menjadi 50 petak berukuran $10 \times 10 \mathrm{~m}$. Setiap individu Nepenthes yang terdapat pada setiap petak ditentukan nama jenisnya, diukur posisinya (koordinatnya), diukur diameter dan panjang batangnya. Data yang terkumpul dianalisis dengan cara $\mathrm{Cox}^{3)}$ dan Greigh-Smith ${ }^{4}$ untuk mendapatkan nilai Luas Bidang Dasar (LBD), Frekuensi Relatif (FR), Kerapatan Relatif (KR), Dominansi Relatif
(DR) dan Nilai Penting (NP). Nilai LBD didapat dari hasil perhitungan rumus:

$$
\operatorname{LBD}=(0,5 \times D) 2 \times 3,14
$$

Dimana $D$ adalah diameter batang dan nilai 3,14 adalah konstanta. Nilai FR merupakan hasil bagi dari frekuensi suatu jenis dengan frekuensi semua jenis dan dikalikan $100 \%$, dimana nilai frekuensi didapat dari jumlah petak ditemukannya suatu jenis dari jumlah petak contoh yang digunakan. Nilai KR merupakan hasil bagi dari kerapatan suatu jenis dengan kerapatan semua jenis dan dikalikan $100 \%$, dimana nilai kerapatan didapat dari jumlah total individu suatu jenis dari seluruh petak. Nilai DR merupakan hasil bagi dari dominansi suatu jenis dengan dominansi semua jenis dan dikalikan $100 \%$, dimana nilai dominansi didapat dari jumlah nilai LBD suatu jenis. Nilai NP didapat dari hasil perjumlahan FR, KR dan DR.

Tingkat keasaman tanah ( $\mathrm{pH}$ tanah) diukur dengan menggunakan soil tester, sedangkan intensitas cahaya diukur dengan menggunakan alat lux meter. Demikian pula dengan $\mathrm{pH}$ cairan pada kantong Nepenthes yang masih tertutup maupun yang sudah terbuka, diukur dengan menggunakan $\mathrm{pH}$ meter.

\section{HASIL DAN PEMBAHASAN}

\subsection{Inventarisasi}

Hasil survei di sekitar lokasi penelitian dapat dilaporkan bahwa hanya ditemukan 3 jenis Nepenthes, yakni; N. gracilis, N. rafflesiana, dan $\mathrm{N}$. ampullaria dengan berbagai variasi warna kantong, diantaranya $\mathrm{N}$. gracilis dengan warna kantong hijau, $\mathrm{N}$. rafflesiana dengan warna kantong bercak coklat kemerah-merahan, dan 3 variasi warna kantong $\mathrm{N}$. ampullaria yaitu hijau polos, bercak merah bibir hijau, dan bercak merah bibir merah. Jumlah jenis ini relatif kecil jika dibandingkan dengan keragaman Nepenthes di hutan kerangas yang pernah ditemukan di Barito Ulu sebanyak 8 jenis ${ }^{5)}$. 
Tipe hutannya termasuk hutan primer yang didominasi oleh pohon Calophyllum canuum, Combretocarpus rotundus dan Cratoxylum glaucum (Alham, 2006., Rahajoe, 2006). Topograpinya datar dengan ketebalan gambut 1-3 m.

Umumnya N. gracilis dan N. rafflesiana ditemukan berbunga/berbuah di tempattempat terbuka di pinggir kanal. Jenis $\mathrm{N}$. gracilis memiliki toleransi tinggi terhadap intensitas cahaya yang diterima. Jenis ini mampu hidup di tempat terbuka maupun terlindung. Namun demikian jenis ini sangat cepat berbunga dan berbuah di tempat terbuka dengan cahaya matahari penuh yang diterima sepanjang hari. Sedangkan jenis $\mathrm{N}$. rafflesiana dan $\mathrm{N}$. ampullaria banyak ditemukan ditempat-tempat agak terlindung.

\subsection{Populasi}

Hasil sensus di dalam plot seluas 0,5 $\mathrm{Ha}(50 \times 100 \mathrm{~m})$ ditemukan sejumlah 230 individu Nepenthes yang terdiri dari 3 jenis, yakni N. rafflesiana, N. ampullaria dan $\mathrm{N}$. gracilis. Hasil analisis dapat dilaporkan bahwa jenis $\mathrm{N}$. ampullaria merupakan jenis dominan dengan Nilai Penting (NP) sebesar $120.43 \%$, kemudian diikuti oleh $\mathrm{N}$. gracilis dengan NP sebesar $97.30 \%$ dan N. rafflesiana dengan NP sebesar $82.27 \%$ (Tabel 1). Meskipun N. gracilis memiliki jumlah individu lebih besar(116) dan penyebaran di dalam plot lebih luas dibanding jenis lainnya (Gambar 1), namun jenis ini memiliki diameter batang sangat kecil, menyebabkan nilai LBDnya jadi kecil, sehingga nilai NPnya juga menjadi kecil. Sebaliknya jenis $\mathrm{N}$. ampullaria meskipun memiliki jumlah individu
(72) dan tingkat penyebarannya lebih kecil daripada $\mathrm{N}$. gracilis, namun $\mathrm{N}$. ampullaria memiliki diameter batang lebih besar yang menyebabkan nilai NP-nya menjadi lebih tinggi daripada N. gracilis, sehingga $\mathrm{N}$. ampullaria tergolong kedalam jenis paling dominan. Dari hasil pengukuran tercatat rata-rata diameter batang, $\mathrm{N}$. gracilis adalah sebesar $1.66 \mathrm{~mm}$, sedangkan $\mathrm{N}$. ampullaria dan N. rafflesiana adalah berturut-turut 6.37 $\mathrm{mm}$ dan $7.54 \mathrm{~mm}$.

Pada luasan yang sama $(0,5$ ha) tingkat keragaman dan kerapatan Nepenthes di hutan rawa gambut tersebut relatif rendah jika dibandingkan dengan hutan kerangas di daerah Barito ulu yang memiliki 8 jenis Nepenthes dengan tingkat kerapatan antara 685 hingga 2325 individu ${ }^{5}$.

Keasaman tanah di dalam plot tercatat rata-rata sebesar 6.1 dan intensitas cahaya rata-rata sebesar 2786,3 lux. Sampel air dari beberapa kanal, air sumur dan air hujan juga diukur sebagai data tambahan. Data yang diperoleh adalah ph air kanal rata-rata 3.72, air sumur 5.3 dan air hujan 4.2. Dengan ph air yang umumnya sangat asam, maka beberapa bakteri pembususk sulit hidup di tempat ini dan mengakibatkan proses pembusukan serasah daun sangat lambat. Dari hasil penelitian diketahui hanya 3 sampai 5 \% laju dekomposisi pertahunnya di tempat ini6). Padahal produksi serasah yang jatuh di lantai hutan adalah sebesar 9,12 ton per tahun per 1 hektar $^{7}$ ), sehingga proses dekomposisi serasah dengan produksi tidak seimbang. Oleh karena itu penumpukan serasah akan terjadi setiap tahunnya.

Pada tabel 2 dapat dilihat bahwa $\mathrm{N}$. ampullaria memiliki rata-rata panjang batang 
Tabel 1. Analisis populasi Nepenthes di dalam plot seluas 0,5 ha di Kalampangan.

\begin{tabular}{|c|c|c|c|c|c|c|c|}
\hline Nepenthes & $\mathrm{F}$ & $\mathrm{K}$ & $\begin{array}{c}\mathrm{BA}(\mathrm{cm} 2 / 5000 \\
\mathrm{m} 2)\end{array}$ & $\mathrm{FR}(\%)$ & $\mathrm{KR}(\%)$ & $\mathrm{DR}(\%)$ & $\mathrm{NP}(\%)$ \\
\hline ampullaria & 28 & 72 & 24,75 & 35,00 & 31,30 & 54,12 & 120,43 \\
\hline gracilis & 33 & 116 & 2,57 & 41,25 & 50,43 & 5,61 & 97,30 \\
\hline rafflesiana & 19 & 42 & 18,41 & 23,75 & 18,26 & 40,26 & 82,27 \\
\hline Sum & 80 & 230 & 45,73 & 100,00 & 100,00 & 99,99 & 299,99 \\
\hline
\end{tabular}

Keterangan: $\mathrm{F}=$ Frekuensi, $\mathrm{K}=$ Kerapatan, $\mathrm{BA}=$ Basal Area, $\mathrm{FR}=$ Frekuensi Relatif, $\mathrm{KR}=$ Kerapatan Relatif, $\mathrm{DR}=$ Dominansi Relatif, $\mathrm{NP}=$ Nilai Penting.

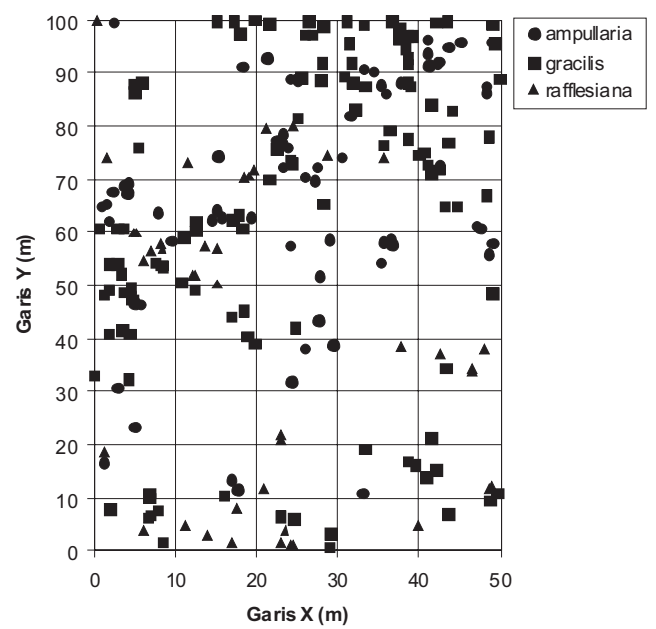

Gambar 1. Pola sebaran Nepenthes di dalam plot seluas 0,5 ha.

lebih tinggi daripada jenis lainnya, namun memiliki jumlah daun lebih sedikit daripada $\mathrm{N}$. gracilis, hal ini karena internodus N. ampullaria lebih panjang daripada N. gracilis. Di lokasi penelitian, pertambahan individu baru umumnya tumbuh dari tunas-tunas cabang yang muncul dari permukaan tanah yang berasal dari induknya. Sedangkan individu baru yang berasal dari biji sangat jarang ditemukan. Hal ini mungkin dikarenakan karena dilokasi ini penutupan kanopi pohonpohonnya cukup rapat sehingga sinar cahaya matahari yang diterima Nepenthes kurang dan tidak mendukung terjadinya proses pembungaan.

Selama penelitian berlangsung, tidak pernah ditemukan adanya individu Nepenthes yang sedang berbunga maupun berbuah di dalam hutan. Sedangkan Nepenthes yang ditemukan hidup di pinggir-pinggir hutan seperti N. gracilis dan N. rafflesiana, mampu berbunga dan berbuah. Dengan demikian intensitas cahaya matahari yang diterima diperkirakan sangat berpengaruh terhadap proses pembentukan bunga Nepenthes.

Pada tabel 3 tidak terlihat adanya perbedaan yang nyata antara $\mathrm{pH}$ cairan Tabel 2. Rata-rata panjang batang, diameter batang dan jumlah daun dari masingmasing jenis Nepenthes yang terukur.

\begin{tabular}{|l|l|l|l|}
\hline Jenis & $\begin{array}{l}\text { Panjang } \\
\text { batang } \\
(\mathrm{cm})\end{array}$ & $\begin{array}{l}\text { Diameter } \\
\text { batang } \\
(\mathrm{mm})\end{array}$ & $\begin{array}{l}\text { Jumlah } \\
\text { daun }\end{array}$ \\
\hline ampullaria & 61,87 & 6.37 & 14,81 \\
\hline gracilis & 54,76 & 1.66 & 19,10 \\
\hline rafflesiana & 39,76 & 7.54 & 13,59 \\
\hline
\end{tabular}

Tabel 3. Rata-rata pH cairan di dalam kantong pada masing-masing jenis Nepenthes di Kalampangan.

\begin{tabular}{|l|l|l|l|}
\hline Jenis & $\begin{array}{l}\text { Bentuk } \\
\text { kantong }\end{array}$ & $\begin{array}{l}\text { Kantong } \\
\text { terbuka }\end{array}$ & $\begin{array}{l}\text { Kantong } \\
\text { tertutup }\end{array}$ \\
\hline gracilis & Bawah & 4.20 & - \\
\hline & Atas & 4.60 & - \\
\hline rafflesiana & Bawah & 4.53 & 3.90 \\
\hline & Atas & 4.17 & - \\
\hline ampullaria & Roset & 5.00 & 4.30 \\
\hline & Bawah & 4.25 & - \\
\hline
\end{tabular}


kantong bawah dan kantong atas pada masing-masing jenis Nepenthes yang terukur, namun demikian ada kecenderungan $\mathrm{pH}$ cairan pada kantong tertutup lebih asam daripada pada kantong terbuka, khususnya pada jenis $\mathrm{N}$. rafflesiana dan N. ampullaria. Hal ini karena cairan pada kantong tertutup adalah murni dari enzim protease, sedangkan cairan pada kantong terbuka sudah bercampur dengan air hujan, bakteri dan serangga yang mati. Tingkat keasaman cairan di dalam kantong diperkirakan sangat berpengaruh terhadap keberadaan bakteri pengurai, juga berperan dalam proses penguraian serangga yang terjebak. Dilaporkan ada kurang lebih antara $10-39$ jenis bakteri yang ditemukan di beberapa kantong Nepenthes. Namun demikian Bakteri dari jenis Achromatium, Bacteroides splanchnicus dan Cytophaga merupakan bakteri yang dominan dan umum dijumpai pada beberapa jenis Nepenthes yang berbeda ${ }^{8}$. Bakteri-bakteri tersebut berperan dalam membantu mendegradasi molekul-molekul besar seperti protein dan kitin pada serangga yang mati terjebak di dalam kantong Nepenthes.

\section{KESIMPULAN}

Ditemukan hanya tiga jenis Nepenthes di hutan rawa gambut Kalampangan, yakni; $\mathrm{N}$. ampullaria, N. gracilis dan $\mathrm{N}$. rafflesiana dengan jenis paling dominan dimiliki oleh $\mathrm{N}$. ampullaria. Hasil survey menunjukkan bahwa tingkat keragaman dan kerapatan Nepenthes di hutan rawa gambut kalampangan relatif rendah jika dibandingkan dengan di hutan kerangas yang ada di daerah Barito Ulu, Kalimantan Tengah.

\section{DAFTAR PUSTAKA}

1. Alham, L., Joeni, S.R. dan Herwint, S. 2006. Decomposition process in peat swamp forest, Kalampangan, Central Kalimantan, Indonesia. Kumpulan abstrak dari International Symposium on Nature and Land Management of
Tropical Peat Land in South East Asia. Bogor, 20-21 Sept 2006. Halaman 76.

2. Boehm, V.H.D. 2006. Peat land topography derived from $30 \mathrm{~m}$ resolution SRTM-X-SAR satelite images for Sebangau catchment and Kahayan area, Kalampangan, Central Kalimantan. Kumpulan absrak International Symposium on Nature And Land Management of Tropical Peat Land in South East Asia. LIPI-JSPS Core University Program, Bogor Indonesia 20-21 September 2006. Hal.59.

3. Cox, G.W. 1967. Laboratory Manual of General Ecology. M.C. Crown, lowa.

4. Greigh-Smith, P. 1964. Quantitative Plant Ecology. Second Edition. Butterworths London.

5. Mansur, M. 2006. Nepenthes Kantong Semar Yang Unik (Buku). Penebar Swadaya, Jakarta. 99 halaman.

6. Mansur, M. 2007. Ecological study of Nepenthes in Barito Ulu, Central Kalimantan, Indonesia. Kumpulan Abstrak. Sarawak Nepenthes Summit, Sarawak 18-21 Agustus, Malaysia.

7. Rahajoe, J.S., dkk. 2006. Production seasonality and decomposition rate of litter of some dominant species in an intact and post-fire peat swamp forests of Central Kalimantan. Kumpulan abstrak dari International Symposium on Nature and Land Management of Tropical Peat Land in South East Asia. Bogor, 20-21 Sept 2006. Halaman 141.

8. Yogiara. 2004. Analisis komunitas bakteri cairan kantung semar (Nepenthes spp.) menggunakan teknik Terminal Restriction Fragment Length Polymorphism (T-RFLP) dan Amplified Ribosomal DNA Restriction Analysis (ARDRA). Tesis Magister Sains. Institut Pertanian Bogor. 
Lampiran foto:

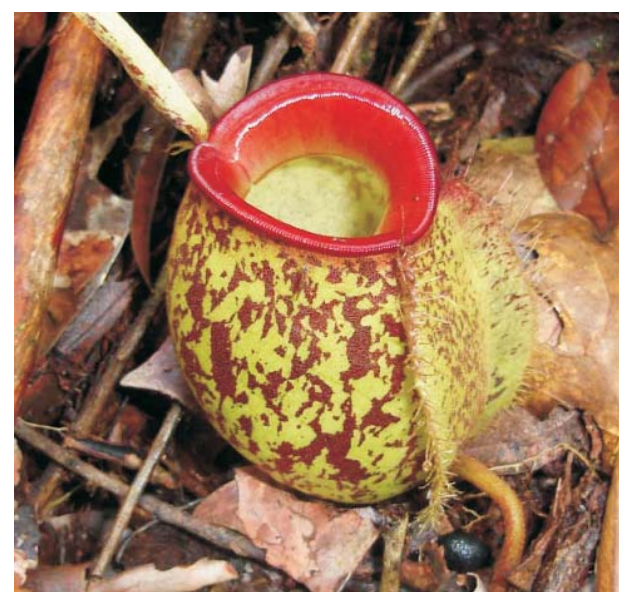

Nepenthes ampullaria bercak coklat bibir merah

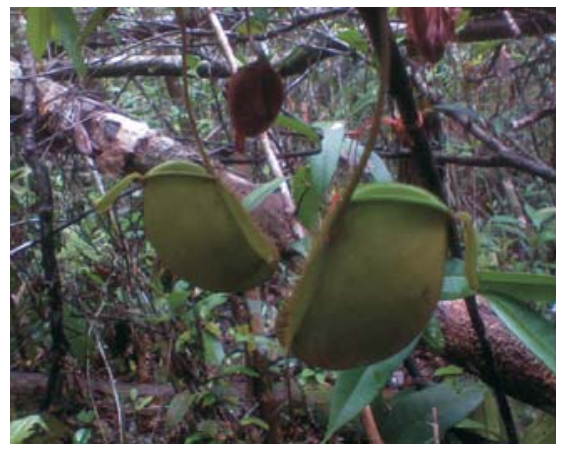

Nepenthes ampullaria hijau polos



Nepenthes gracilis



Nepenthes rafflesiana

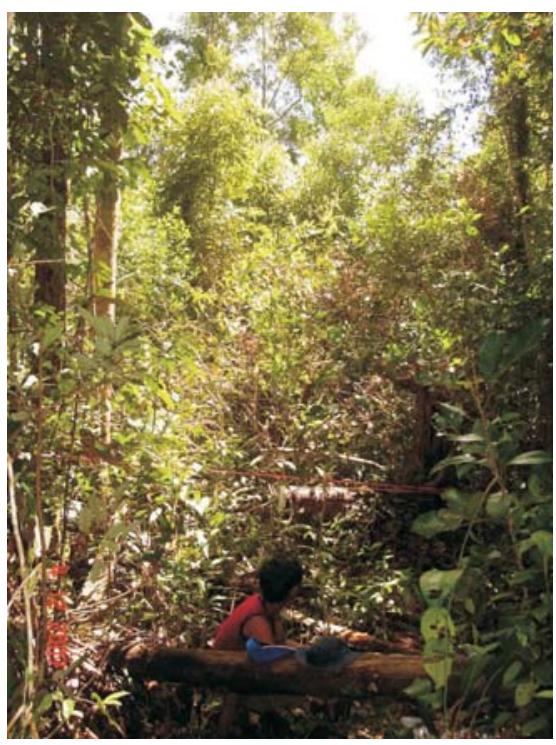

Plot di hutan rawa gambut, Kalampangan 